Dept. of Animal Hygiene and Zoonoses,

Fac. Vet. Medicine, Assiut University, Egypt.

\title{
EPIDEMIOLOGICAL STUDY ON TRICHINELLOSIS IN PIGS AND MAN IN UPPER EGYPT
}

(With 5 Tables)

\author{
By \\ AMAL S.M. SAYED; ASMAA A.A. HUSSEIN; \\ M.I. ARAFA* and B.R.N. ABDO* \\ *Animal Health Research Institute, Assiut, Egypt.
}

(Received at 27/2/2010)

دراسة وبائية على الترايكينوسيس في الخنازير والإنسان في صعيد مصر

أمل سبي محد سبي ، أسعاء عبل الناصر حسين ، مصسن عرفه ،

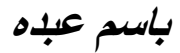

تعتبر الإصابة بالترايكينوسيس من أهم الأمر اض الطفيلية على مستوى العالم ليس فقط لتأثيرها

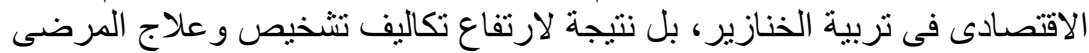

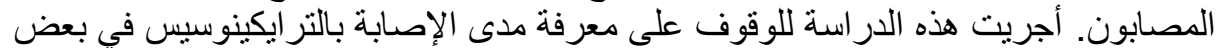

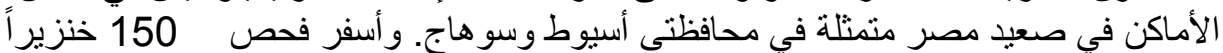

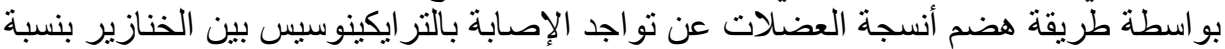

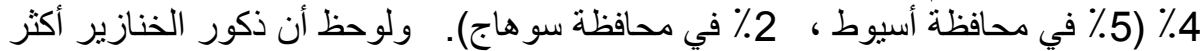

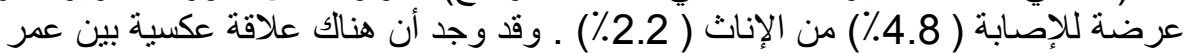

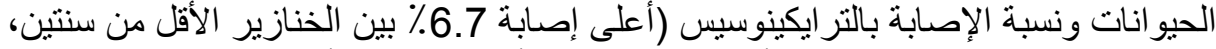

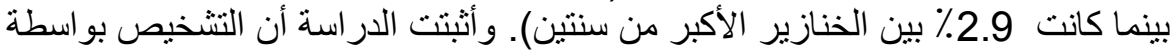

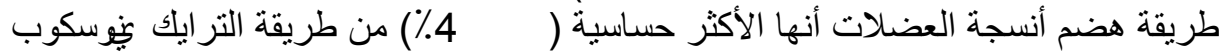

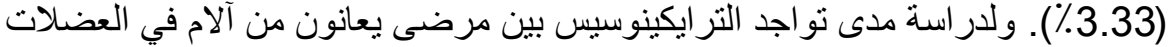

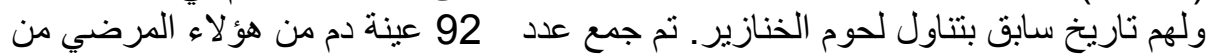

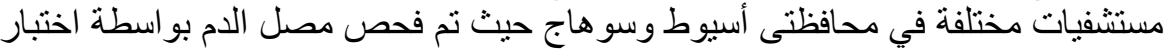

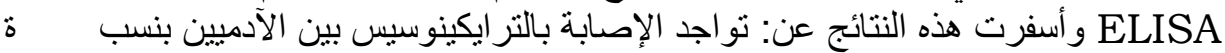

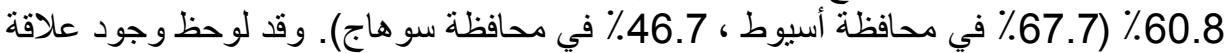

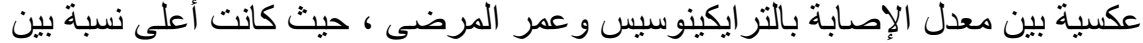

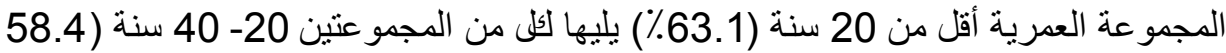
\%) ثم أكبر من 40 سنة (25\%). 


\section{SUMMARY}

Trichinellosis is one of the most widespread zoonotic parasitic diseases of animals and man allover the world. This study aimed to determine the occurrence of Trichinella spiralis among pigs and humans in Assiut and Sohag Governorates in Upper Egypt. Trichinellosis was detected in $4.0 \%$ of the examined pigs with a prevalence rate of $5.0 \%$ and $2.0 \%$ in Assiut and Sohage Governorates, respectively. Male pigs were more susceptible $(4.8 \%)$ than females $(2.2 \%)$. There was a reverse relationship between the age of pigs and the occurrence of Trichinellosis. Diagnosis of Trichinella spiralis by digestion technique (4.0\%) showed to be more sensitive than trichinoscope $(3.33 \%)$ examination. Incidence of Trichinellosis in human was $60.8 \%$ with a rate of $67.7 \% \%$ in Assiut Governorate and $46.7 \%$ in Sohage Governorate by using ELISA. There was a reverse relationship between the patient's age and the occurrence of Trichinellosis. Higher occurrence of Trichinellosis was detected in female patients $(61.8 \%)$ than males $(56.3 \%)$.

Key words: Trichinellosis, trichinoscope, ELISA, pigs,man.

\section{INTRODUCTION}

Trichinellosis is one of the most widespread zoonotic parasitic diseases of animals and man allover the world in most climates except for deserts (Dupouy-Camet, 2000). It is caused by a nematode parasite belonging to the genus Trichinella, which is an obligate intracellular parasite in both larval and immature adult stage (Capó and Despommier, 1996). It has a wide range of hosts and over 150 mammalian species and birds as well as reptiles have been found to be infected worldwide. Eight Trichinella species containing 11 genotypes have been identified and no morphological differences exist between the species and genotypes. However, they have been differentiated from each other by molecular and biochemical methods (Pozio, 2005).

Pigs are the main reservoir of human trichinellosis and they acquire the infection through feeding on raw pork scraps from slaughterhouses and garbage. Also the cannibalistic behavior of pigs plays a role in transmission of trichinellosis (Pozio, 2001). On the other hand, human acquires trichinellosis by ingesting raw or insufficiently cooked pork meat and other animals (horses and dogs) containing the larvae of Trichinella (Dupouy-Camet, 2000). 
In Egypt, the disease was not given much importance and was believed to be absent (Rifaat et al., 1969) until the first case of human trichinellosis was recorded by Morcos et al. (1978) in Alexandria. Thereafter, several cases were reported in different localities. On the other hand, few studies are available on trichinellosis in Upper Egypt and most of their localities have no records on it. Therefore, the present study aimed to study the occurrence of Trichinella spiralis among pigs and humans in Assiut and Sohag Governorates in Upper Egypt.

\section{MATERIALS and METHODS}

Detection of trichinellosis in pigs: A total of 150 slaughtered pigs (1.53 years) were selected randomly from Assiut and Sohag Governorates during the period from May, 2006 to June, 2007. Muscular part of the diaphragm and diaphragm pillar muscles of each pig were collected and kept at $-20^{\circ} \mathrm{C}$ until the time of the examination.

Trichinoscopic examination: Small pieces of muscle $(2 \mathrm{~mm} \times 10 \mathrm{~mm})$ were compressed between two glass plates until they became translucent and examined individually for Trichinella larvae by using the compound microscope (15- 40 x magnification) (Gamble, 1996).

Artificial digestion method: Pieces of examined tissue $(4 \mathrm{~g})$ were digested in $100 \mathrm{ml}$ of $1 \%(\mathrm{w} / \mathrm{v})$ pepsin and $1 \%(\mathrm{v} / \mathrm{v})$ hydrochloric acid $(0.12 \mathrm{~N}$ final) and the mixture was kept on a magnetic stirrer for 3 hours at $37^{\circ} \mathrm{C}$. Sediment was suspended, sieved and examined under a dissecting microscope for the presence of larvae (Gamble, 1996).

Detection of trichinellosis in human: Serum samples were obtained from patients attended Assiut health center (62) and Sohag teaching hospital (30) presented with at least three of the following symptoms and/or signs; fever, myalgia, edema, eosinophilia and digestive disorders together with history of eating pork. The collected sera were coded and kept at $-20^{\circ} \mathrm{C}$ until examined by ELISA. ELISA assay was performed as described by Ribicich et al. (2000) by using Trichinella IgG ELISA kit (Ridascreen No. K 7521, R-Biopharm company AG, Landwehrstr. 54, D-64293 Darmstadt, Germany).

Statistical analysis: Statistical analyses were carried out using SPSS 14 (SPSS Inc., Chicago, IL, USA http://www.spss.com). The $\chi^{2}$ test was used for analyzing differences between the results. 


\section{RESULTS}

Table 1: Prevalence of Trichinella spiralis in pigs with relation to age

\begin{tabular}{|c|c|c|c|c|c|c|c|c|c|}
\hline \multirow[b]{2}{*}{ 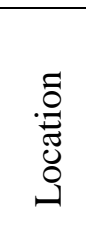 } & \multirow[b]{2}{*}{ 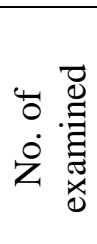 } & \multirow[b]{2}{*}{ 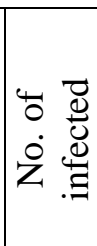 } & \multirow[b]{2}{*}{$b^{\circ}$} & \multicolumn{3}{|c|}{ Below 2 years } & \multicolumn{3}{|c|}{ Above 2 years } \\
\hline & & & & 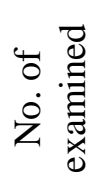 & $\begin{array}{l}\text { प. } \\
0.00 \\
\dot{0} \\
\dot{0}\end{array}$ & $b^{\circ}$ & 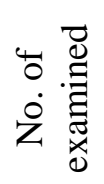 & 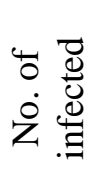 & $b^{\circ}$ \\
\hline A & 100 & 5 & 5 & 30 & 3 & 10 & 70 & 2 & 2.9 \\
\hline B & 50 & 1 & 2 & 15 & - & 0 & 35 & 1 & 2.9 \\
\hline Total & 150 & 6 & 4 & 45 & 3 & 6.7 & 105 & 3 & 2.9 \\
\hline
\end{tabular}

A: Assiut Governorate B: Sohag Governorate $*\left(\chi^{2}=1.190, p=0.275\right)$

Table 2: Sex distribution of Trichinella spiralis among pigs

\begin{tabular}{|c|c|c|c|c|c|c|}
\hline \multirow[b]{2}{*}{ Location } & \multicolumn{3}{|c|}{ Males } & \multicolumn{3}{|c|}{ Females } \\
\hline & 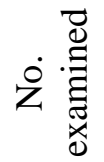 & 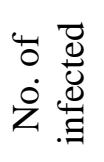 & 82 & 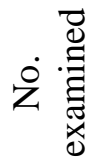 & 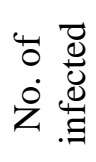 & $b^{\circ}$ \\
\hline A & 71 & 4 & 5.6 & 29 & 1 & 3.5 \\
\hline B & 33 & 1 & 3 & 17 & - & - \\
\hline Total & 104 & 5 & 4.8 & 46 & 1 & 2.2 \\
\hline
\end{tabular}

A: Assiut Governorate B: Sohag Governorate

$*\left(\chi^{2}=0.576, p_{=} 0.448\right)$

Table 3: Detection of trichinellosis in pigs

\begin{tabular}{|c|c|c|c|c|c|}
\hline \multirow[b]{2}{*}{ 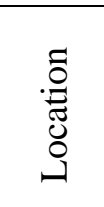 } & \multirow[b]{2}{*}{ 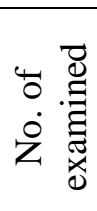 } & \multicolumn{2}{|c|}{ Muscle digestion } & \multicolumn{2}{|c|}{ Trichinoscopic examination } \\
\hline & & 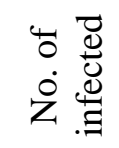 & $d^{e}$ & 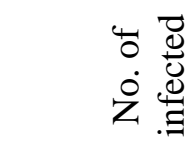 & $d^{e}$ \\
\hline A & 100 & 5 & 5 & 4 & 4 \\
\hline B & 50 & 1 & 2 & 1 & 2 \\
\hline Total & 150 & 6 & 4 & 5 & 3.33 \\
\hline
\end{tabular}

A: Assiut Governorat B: Sohag Governorate $\quad *\left(\chi^{2}=0.0944, p_{=} 0.759\right)$ 
Table 4: Sex distribution of human trichinellosis

\begin{tabular}{|c|c|c|c|c|c|c|c|c|c|}
\hline \multirow[b]{2}{*}{ Location } & \multirow[b]{2}{*}{ 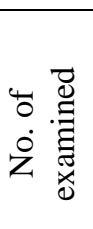 } & \multirow[b]{2}{*}{ 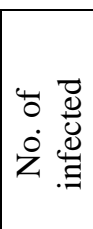 } & \multirow[b]{2}{*}{$b^{\circ}$} & \multicolumn{3}{|c|}{ Men } & \multicolumn{3}{|c|}{ Women } \\
\hline & & & & 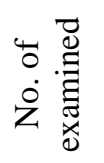 & 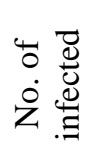 & $b^{\circ}$ & 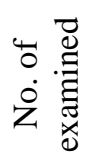 & 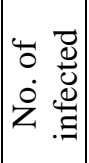 & $\delta^{\circ}$ \\
\hline A & 62 & 42 & 67.7 & 5 & 3 & 60 & 57 & 39 & 68.4 \\
\hline B & 30 & 14 & 46.7 & 11 & 6 & 54.5 & 19 & 8 & 42.1 \\
\hline Total & 92 & 56 & 60.9 & 16 & 9 & 56.3 & 76 & 47 & 61.8 \\
\hline
\end{tabular}

A: Assiut Governorate B: Sohag Governorate $\quad *\left(\chi 2=0.174, p_{=} 0.677\right)$

Table 5: Age distribution of trichinellosis in human

\begin{tabular}{|c|c|c|c|c|c|c|c|c|c|}
\hline \multirow[b]{2}{*}{ Location } & \multicolumn{3}{|c|}{$4-<20$ years } & \multicolumn{3}{|c|}{20 - 40 years } & \multicolumn{3}{|c|}{$>40$ years } \\
\hline & 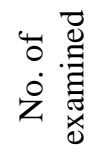 & 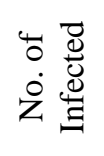 & $d^{0}$ & 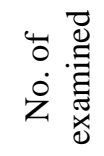 & 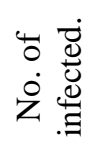 & $\partial^{0}$ & 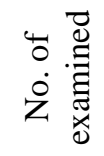 & 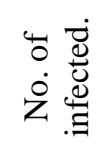 & $\partial^{0}$ \\
\hline A & 14 & 11 & 78.5 & 45 & 30 & 66.7 & 3 & 2 & 66.7 \\
\hline B & 5 & 1 & 20 & 20 & 8 & 40 & 5 & - & - \\
\hline Total & 19 & 12 & 63.2 & 65 & 38 & 58.5 & 8 & 2 & 25 \\
\hline
\end{tabular}

A: Assiut Governorate B: Sohag Governorate $\quad *(\chi 2=3.675, p=0.159)$

\section{DISCUSSION}

In this study, the occurrence of $T$. spiralis among the examined pigs was $4.0 \%$ by using muscle digestion technique (Table 1). The obtained result coincides with the results obtained by El-Nawawy (1981) and considered higher than that recorded by Morsy et al. (2000). It was lower than those reported by Yassien et al. (1989). The difference in the reported prevalence rates are expected and attributed to difference in the localities, methods for detection, control measures applied as well as 
management and feeding of pigs in such countries. Higher prevalence rate was detected in Assiut Governorate (5\%) than Sohag Governorate ( $2 \%)$ and may be attributed to the free rearing of pigs and feeding of pigs on food waste or garbage.

Trichinellosis was higher in pigs below 2 years $(6.7 \%)$ than in pigs above 2 years $(2.9 \%)$ and was not statistically significant (Table1). Similar finding was reported previously and attributed to the incomplete development of immune system of young pigs (Monroy et al., 2001).

Trichinellosis was detected in $4.8 \%$ of males and $2.2 \%$ of females (Table 2) although the difference was not statistically significant. The obtained result coincides with Cowen et al. (1990). The higher resistance of females was attributed to the effect of female sex hormone (progesterone) which increases the parasiticidal effect of the leukocytes involved in the death of the newly born larvae (Nunez et al., 2005).

Muscle digestion technique was more sensitive (4\%) than the compression method (3.33\%) (Table 3) however, the variation was not statistically significant.Our result coincides with the results obtained by El-Nawawy (1981). Conversely, it is considered higher than that recorded by Morsy et al. (2000) and lower than those reported by Yassien et al. (1989). Although trichinoscope is the technique that still used in the Egyptian abattoirs and many countries to detect trichinellosis and it offers the advantage that each pig is examined individually and the results can be obtained shortly after slaughtering, but it is less reliable in very mild infection and very difficult to demonstrate the nonencysted larvae. For this reason, it is recommended to use muscle digestion technique due to its better sensitivity.

Diagnosis of trichinellosis in human by using indirect ELISA test is the most sensitive test in comparison of other immunological tests like indirect haemagglutination, latex agglutination and indirect immunofluorescence. The sensitivity of the IgG-ELISA reaches $100 \%$ on the $50^{\text {th }}$ day and the test remains positive for more than 2 years in $88 \%$ of the infected people (Morakote et al., 1992). In this study trichinellosis was detected in $60.9 \%$ of the examined humans by using ELISA. The obtained prevalence was lower than that reported by Barennes et al. (2008) and higher than that obtained by Wang et al. (2006).

Results illustrated in (Table 4) reveal that women were more susceptible to infection $(61.8 \%)$ than men $(56.3 \%)$ however, it was not statistically significant. Similar finding were reported by De-la-Rosa 
et al. (1998). On the contrary the obtained results disagreed with that obtained by Turk et al. (2006). Moreover, Wang et al. (2006) did not found significant effect of the patient's sex in the prevalence of T. spiralis.

A reverse relationship between the age of the examined patient and trichinellosis was reported in our study. Higher seroprevalence were recorded in young $(63.2 \%)$ and middle aged (58.5\%) groups while, it was $25 \%$ in patients aged above 40 years (Table 5) and it was not statistically different. The obtained results coincide with that reported by Wang et al. (1997). In conclusion, trichinellosis is considered a public health problem in Upper Egypt. Control of trichinellosis among human need prevention of illegal slaughtering of pigs outside slaughterhouses.

Acknowledgements: Great thanks to staff members of health center in Assiut Governorate and Sohag teaching hospital for their great help in selecting human cases.

\section{REFERENCES}

Barennes, H.; Sayasone, S.; Odermatt, P.; De Bruyne, A.; Hongsakhone, S.; Newton, P.N.; Vongphrachanh, P.; Martinez-Aussel, B.; Strobel, M. and Dupouy-Camet, J. (2008): A major trichinellosis outbreak suggesting a high endemicity of Trichinella infection in northern Laos. Am. J. Trop. Med. Hyg. 78, 40.

Capó, V. and Despommier, D.D. (1996): Clinical aspects of infection with Trichinella spp. Clin. Microbiol. Rev. 9, 47.

Cowen, P.; Li, S.G. and McGinn, T. 3rd. (1990): Survey of trichinellosis in breeding and cull swine, using an enzyme-linked immunosorbent assay. Am. J. Vet. Res. 51, 924.

De-la-Rosa, J.L.; Aranda, J.G.; Padilla, E. and Correa, D. (1998): Prevalence and risk factors associated with serum antibodies against Trichinella spiralis. Int. J. Parasitol. 28, 17.

Dupouy-Camet, J. (2000): Trichinellosis: a worldwide zoonosis. Vet. Parasitol. 93, 191.

El-Nawawy, F.A. (1981): Trichinella spiralis in Egypt. Arch. Lebensmittelhyg. 32, 156.

Gamble, H.R. (1996): Trichinellosis. In: OIE (Ed.), Manual of Standards for Diagnostic Tests and Vaccines. List A and B Diseases of Mammals, Birds and Bees. Office International Des Epizooties, Paris, Chapter 3.5.3, pp. 477-480. 
Monroy, H.; Flores-Trujillo, M.; Benitez, E. and Arriaga, C. (2001): Swine trichinellosis in slaughterhouses of the metropolitan area of Toluca. Parasite 8, 249.

Morakote, N.; Sukhavat, K.; Khamboonruang, C.; Siriprasert, V.; Suphawitayanukul, S. and Thamasonthi, W. (1992): Persistence of IgG, IgM and IgE antibodies in human trichinellosis. Trop. Med. Parasitol. 43, 67.

Morcos, W.M. (1978): The first diagnosed case of trichinellosis in Egypt. J. Egypt. Soc. of Parasitol. 18, 121.

Morsy, T.A.; Ibrahim, B.B.; Haridy, F.M. and Rifaat, M.M. (2000): Trichinella encysted larvae in slaughtered pigs in Cairo (1995- 1999). J. Egypt. Soc. Parasitol., 30, 753.

Nunez, G.G.; Gentile, T.; Costantino, S.N.; Sarchi, M.I. and Venturiello, S.M. (2005): In vitro and in vivo effects of progesterone on Trichinella spiralis newborn larvae. Parasitol. 131, 255.

Pozio, E. (2001): New patterns of Trichinella infection. Vet. Parasitol. 98, 133.

Pozio, E. (2005): The broad spectrum of Trichinella hosts: From cold- to warm-blooded animals. Vet. Parasitol. 132, 3.

Ribichi, M.; Gamble, H.R.; Santillan, G.; Miguez, M.; Guarnera, E.; Basso, N. and Franco, A. (2000): Evaluation of ELISA test for the diagnosis of porcine trichinellosis. Pig Journal 46, 24.

Rifaat, M.A.; Mahdi, A.H. and Arafa, M.S. (1969): Further evidence that Egypt is Trichinella free. J. Egypt. Public Health Assoc. 44, 193.

Turk, M.; Kaptan, F.; Turker, N.; Korkmaz, M.; El, S.; Ozkaya, D.; Ural, S.; Vardar, I.; Alkan, M.Z.; Coskun, N.A.; Turker, M. and Pozio, E. (2006): Clinical and laboratory aspects of a trichinellosis outbreak in Izmir, Turkey. Parasite 13, 65.

Wang, Z.; Cai, J.; Wa, F. and Jin, X. (1997): Seven outbreaks of trichinellosis in China (1992-1996). J. Egypt. Soc. Parasitol. 27, 529.

Wang, Z.Q.; Cui, J. and Xu, B.L. (2006): The epidemiology of human trichinellosis in China during 2000-2003. Acta Trop. 97, 247.

Yassien, M.; Abd EL-Rahman, H.; Ibrahim, A. and Mousa, M. (1989): Prevalence of encysted larvae of Trichinella spiralis in pork and beef meat products with special reference to the effect of rapid heat treatment on their viability. Assuit Vet. Med. J. 21, 84. 
Assiut Vet. Med. J. Vol. 56 No. 125 April 2010 